\title{
KAJIAN KUALITAS AIR DAN PERTUMBUHAN IKAN NILA (Oreochromis niloticus) YANG DIBUDIDAYAKAN DENGAN SISTEM AKUAPONIK
}

\author{
Deidy Azhari $^{\mathbf{1}^{*}}$ dan Aprelia Martina Tomasoa ${ }^{2}$ \\ ${ }^{1,2}$ Program Studi Teknologi Budidaya Ikan, Politeknik Negeri Nusa Utara, Tahuna \\ *E-mail korespondensi: wdazhari@yahoo.co.id
}

\begin{abstract}
Abstrak
Kualitas air memegang peranan penting dalam meningkatkan produksi budidaya ikan. Ikan nila (Oreochromis niloticus) merupakan salah satu ikan yang dibudidayakan secara luas di banyak negara termasuk Indonesia. Sebagai salah satu upaya untuk meningkatkan produksi, budidaya ikan nila dilakukan secara intensif yang dicirikan dengan padat tebar tinggi dan pemberian pakan berprotein tinggi. Kontrol kualitas air yang baik menjadi kunci keberhasilan budidaya secara intensif ini. Sistem akuaponik merupakan sistem kombinasi antara sistem akuakultur dan hidroponik yang memiliki prinsip resirkulasi yang bertujuan untuk pengontrolan kualitas air. Berdasarkan hal di atas maka penelitian yang dilakukan bertujuan untuk mengetahui efektivitas sistem akuaponik dalam mengkonversi senyawa amoniak dan memperbaiki kualitas air dalam media budidaya serta mengetahui korelasi antara kualitas air dan pertumbuhan ikan nila. Penelitian dilakukan selama 30 hari untuk mengukur beberapa parameter kualitas air yaitu suhu, Dissolve Oxygen, derajat keasaman (pH), amonia dan nitrat serta parameter pertumbuhan dan sitasan ikan nila yang dibudidayakan. Penelitian ini menggunakan dua variabel dengan tiga kali pengulangan setiap variabelnya. Hasil yang diperoleh menyatakan bahwa sistem akuaponik mampu mereduksi senyawa amonia dan mengkonversinya menjadi senyawa nitrat yang dimanfaatkan untuk pertumbuhan tanaman. Sistem akuaponik juga mampu menjaga kualitas air yang berpengaruh terhadap pertumbuhan dan kelangsungan hidup ikan nila yang dibudidayakan.
\end{abstract}

Kata kunci: akuaponik, amonia, nila, nitrat, pertumbuhan

\section{STUDY OF WATER QUALITY AND GROWTH PERFORMANCE OF NILE TILAPIA (Oreochromis niloticus) REARED IN AQUAPONIC SYSTEM}

\begin{abstract}
Water quality are important key to improved production in fish culture. Nile tilapia (Oreochromis niloticus) is a widely cultivated species all around the world included in Indonesia. To improved Nile tilapia production, cultivation is established intensively characterized with high density population and high protein meals. It must be conducted with a good control of water quality. Aquaponic system is a recirculation system that combined hydroponic and aquaculture in one system intentionally to control and maintain water quality in aquaculture system. Based on what are described above, this research aimed to elucidate the effectivity of aquaponic to converted ammonia from the system and then maintain the water quality and to know the correlation between water quality and growth performance. This research in established for 30 days to measure some water quality parameter such as temperature, Dissolve oxygen, $\mathrm{pH}$, Ammonia, Nitrate, Growth performance and survival rate of cultivated fish. Two variables are used in this research with tree times repetition each variable. Result showed that aquaponic system is able to maintenance water quality by rducing ammonia and converted it into nitrate that been used by plants to growth. By maintained water quality, aquaponic system also able to support and increased growth performance and survival rate of Nile tilapia.
\end{abstract}

Key words: aquaponic, ammonia, growth, nitrate, tilapia

\section{PENDAHULUAN}

Berbagai proses metabolisme yang terjadi di dalam tubuh ikan yang berperan penting dalam produktivitas dan kelangsungan hidup dipengaruhi oleh berbagai faktor fisik kualitas air (Dauhan dkk.,2014). Beberapa faktor fisik yang menjadi parameter kualitas air dalam budidaya ikan air tawar diantaranya suhu, $\mathrm{pH}$ (power of Hydrogen), DO (Dissolve Oxygen), ammonia, nitrat (Marlina dan Rakhmawati, 2016). Budidaya ikan secara intesif dapat menurunkan kualitas air yang berpengaruh terhadap proses-proses fisiologis, termasuk pertumbuhan dan kelangsungan hidup ikan yang dibudidayakan sebagai akibat dari akumulasi limbah sisa pakan dan hasil metabolisme (Effendi dkk., 2015). Akumulasi senyawa amonia dari limbah sisa pakan dan hasil metabolisme dapat menjadi toksik yang menurunkan produktivitas dan kelangsungan ikan yang dibudidayakan (Effendi dkk., 2015; Marlina dan Rakhmawati, 2016).

Dalam rangka pemenuhan gizi masyarakat, ikan nila merupakan salah satu komoditas perikanan air tawar yang mendapat perhatian dan sering dibudidayakan. Hal ini sangat beralasan mengingat kandungan nutrisi seperti protein, terdapat dalam jumlah yang cukup tinggi dalam daging ikan nila (Marlina dan Rakhmawati, 2016). Sebagai upaya untuk meningkatkan produksi, budidaya ikan nila dilakukan secara intesif yang dicirikan dengan padat tebar dan pakan berkandungan protein tinggi (Setijaningsih dan Gunadi, 2016). Seperti yang telah disebutkan sebelumnya, kegiatan budidaya secara intesif memiliki dampak yang negatif terhadap kualitas air dalam kolam budidaya. Upaya-upaya peningkatan produksi dalam budidaya ikan nila diharapkan diikuti dengan metode-metode yang ramah lingkungan dan praktis untuk menjaga kualitas 
air kolam budidaya sehingga pertumbuhan yang optimal dan kelangsungan hidup yang tinggi bisa dicapai.

Sistem akuaponik pada prinsipnya merupakan sistem terinegrasi dari sistem budidaya tanaman (hidroponik) dan akuakultur (Nugroho dkk., 2012; Wijaya dkk., 2014; Hermawan, 2015). Fungsi utama dari sistem ini yaitu untuk optimalisasi fungsi air dan bioremidiasi air yang memanfaatkan tanaman dalam sistem budidaya ikan (Nugroho dkk., 2012). Sistem akuaponik merupakan salah satu cara untuk memperbaiki kualitas air dan mengurangi penggunaan air untuk budidaya ikan sehingga diharapkan bisa menjadi metode alternatif dalam mengontrol kualitas air sehingga dapat meningkatkan pertumbuhan dan kelangsungan hidup ikan yang dibudidayakan.

Sebagai salah satu daerah yang sedang berkembang, Kabupaten Kepulauan Sangihe Propinsi Sulawesi Utara, mengalami salah satu persoalan yang sering dialami daerah-daerah berkembang lainya yaitu ketersediaan lahan dan sumber daya air untuk budidaya perikanan air tawar. Teknologi akuaponik merupakan salah satu teknologi dalam budidaya ikan dan tanaman yang relatif baru dan jarang diterapkan di kabupaten ini. Informasi serta kajian dasar mengenai efisiensi teknologi akuaponik dalam mengatur dan memperbaiki kualitas air dalam bududaya ikan air tawar yang secara langsung dapat meningkatkan pertumbuhan dan kelangsungan hidup ikan yang dibudidayakan sangat dibutuhkan. Hal ini diperelukan sebagai refersensi dan acuan untuk aplikasi teknologi akuaponik dalam skala rumah tangga. Dari beberapa uraian di atas, adapun tujuan yang ingin dicapai yaitu untuk mengetahui efektivitas sistem akuaponik dalam mereduksi senyawa amoniak dan memperbaiki kualitas air dalam media budidaya serta mengetahui korelasi antara kualitas air dan pertumbuhan ikan nila.

\section{BAHAN DAN METODE}

Untuk mengetahui efektivitas sistem akuaponik dalam mereduksi senyawa amonia dan memperbaiki kualitas air dalam media budidaya yang secara langsung meningkatkan pertumbuhan dan kelangsungan hidup ikan nila yang dibudidayakan, beberapa persiapan dan pengukuran dilakukan dalam penelitian ini. Penelitian dilakukan selama 30 hari, ikan yang digunakan adalah ikan nila (Oreochromis niloticus) dengan ukuran $74 \pm 4$ g/ekor sebanyak 90 ekor yang didistribusikan pada dua kelompok perlakuan yaitu perlakuan kolam kontrol dan kolam dengan sistem akuaponik dengan 3 kali pengulangan setiap kelompok perlakuan. Ikan yang digunakan dalam setiap kolamnya sebanyak 15 ekor.

Wadah budidaya yang digunakan adalah kolam terpal dengan ukuran 120x60x60 cm dengan volume air $100 \mathrm{~L}$ setiap kolamnya. Kolam-kolam perlakuan dan kontrol ditempatkan saling berhadapan menggunakan naungan berupa jaring hapa dengan mess size kecil yang ditempatkan pada ketinggian $2 \mathrm{~m}$ dari permukaan kolam. Sistem sirkulasi yang digunakan adalah sistem resirkulasi dimana pada kolam kontrol menggunakan penyaring berupa spons saringan sedang pada kolam akuaponik menggunakan sistem akuaponik. Pada sistem akuaponik, tanaman yang digunakan adalah kangkung tanah (Ipomoea reptans) dengan kepadatan 5 tanaman $/ 5 \mathrm{~cm} 2$, sedangkan media tanam digunakan adalah arang kayu dan kerikil halus. Untuk pakan yang digunakan adalah pakan komersil merek MG-2 yang diberikan sebanyak 2 kali sehari secara ad satiation.

Parameter kualitas air yang diukur yaitu suhu, DO, pH, amonia dan nitrat. Pengukuran suhu dilakukan dengan menggunakan thermometer alkohol $100^{\circ} \mathrm{C}$, DO dan $\mathrm{pH}$ menggunakan DO dan $\mathrm{pH}$ meter merek EUTECH INSTRUMENT CyberScan Series 600, sedangkan amonia dan nitrat diukur dengan menggunakan SERA aqua-test kit. Parameter pertumbuhan dan kelangsungan hidup dihitung dengan menggunakan persamaan SGR (Specific Growth Rate) atau laju pertumbuhan spesifik dan SR (Survival Rate) atau sintasan (Effendi, 1997). Rasio konversi pakan juga dihitung dengan menggunakan persamaan rasio konversi pakan (FCR) (Effendi, 1997).

$$
S G R=\left(\frac{\ln W_{t}-\ln W_{0}}{t}\right) \times 100
$$

Keterangan:

SGR = Laju pertumbuhan $\operatorname{Spesifik~}(\%)$

$\mathrm{Wt}=$ Berat ikan pada akhir pemeliharaan $(\mathrm{g})$

$\mathrm{W}_{0} \quad=$ Berat ikan pada awal pemeliharaan $(\mathrm{g})$

$\mathrm{t} \quad=$ Waktu pemeliharaan (hari)

$$
S R=(N t / N O) \times 100
$$

Keterangan:

$\mathrm{SR} \quad=$ Tingkat kelulushidupan ikan $(\%)$

$\mathrm{N}_{0} \quad$ = Jumlah ikan pada awal penelitian (ekor)

$\mathrm{N}_{\mathrm{t}} \quad=$ Jumlah ikan pada akhir penelitian (ekor)

$$
\mathbf{F C R}=\frac{\mathbf{F}}{\Delta \mathbf{W}}
$$

Keterangan :

FCR = Rasio konversi pakan $(\mathrm{g})$

$\mathrm{F} \quad=$ Jumlah pakan yang diberikan selama penelitian $(\mathrm{g})$

$\Delta \mathrm{W}=$ Bobot akhir-bobot awal $(\mathrm{g})$

\section{HASIL DAN PEMBAHASAN}

Hasil pengukuran parameter kualitas berupa suhu, DO, pH, amonia dan nitrat disajikan dalam bentuk grafik rata-rata fluktuasi setiap parameter di kedua sistem selama masa perlakuan, sedangkan 
parameter peretumbuhan disajikan dalam bentuk histogram.

\section{Suhu}

Hasil menunjukan kisaran hampir sama antara kedua sistem yang digunakan. Hal ini dapat terjadi karena lokasi kolam yang sama yang menjadikan sebaran suhu yang hapir sama. Kisaran suhu optimal dalam budidaya ikan air tawar adalah 28-32 ${ }^{\circ} \mathrm{C}$ (Mas'ud, 2014), sedangkan menurut Gupta and Acosta (2004), kisaran suhu yang baik untuk budidaya ikan nila adalah $25-30^{\circ} \mathrm{C}$. Hasil yang diperoleh dalam penelitian ini dapat dikatakan optimal untuk pertumbuhan ikan nila yang dibudidayakan baik pada kolam akuaponik maupun kolam konvensional.

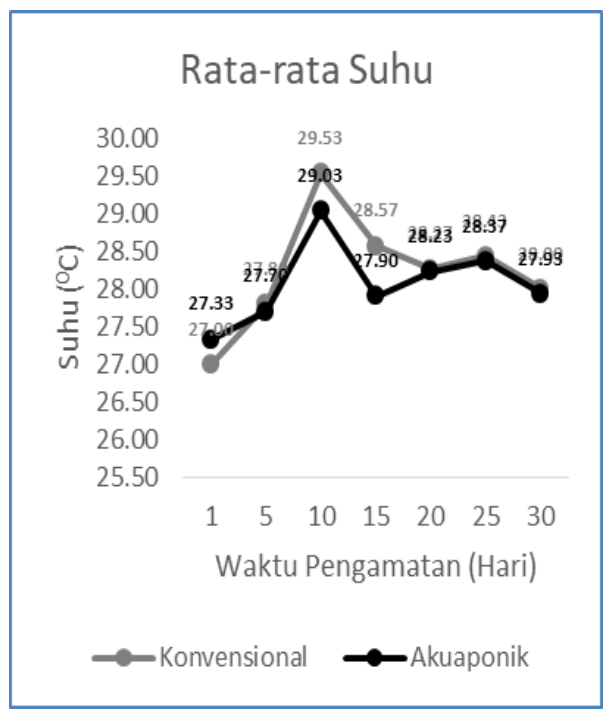

Gambar 1. Fluktuasi suhu pada kedua sistem selama masa perlakuan

\section{Dissolved Oxygen (DO)}

Hasil menunjukan kondisi DO yang relatif stabil pada pada sistem akuaponik sedangkan pada sistem konvensional DO mengalami penurunan pada hari ke 15 yang berpengaruh terhadap kelangsungan hidup ikan yang dibudidayakan. Hal ini terjadi akibat adanya pengaruh partikel-partikel terlarut dalam air (Mas'ud, 2014), dimana kolam konvensional memiliki kelarutan partikel terlarut lebih tinggi dibandingkan dengan kolam akuaponik yang dapat dilihat pada Gambar 4. Dari hasil yang diperoleh ini dapat dikatakan bahwa kolam akuaponik dapat mempertahankan kondisi oksigen terlarut sebagai akibat dari kelarutan partikelpartikel dalam air yang kecil. Sejalan dengan hasil yang diperoleh dalam penelitian Putra dkk. (2013); Dauhan dkk. (2014), bahwa sistem akuaponik memiliki tingkat DO yang stabil sebagai parameter kualitas air yang baik.

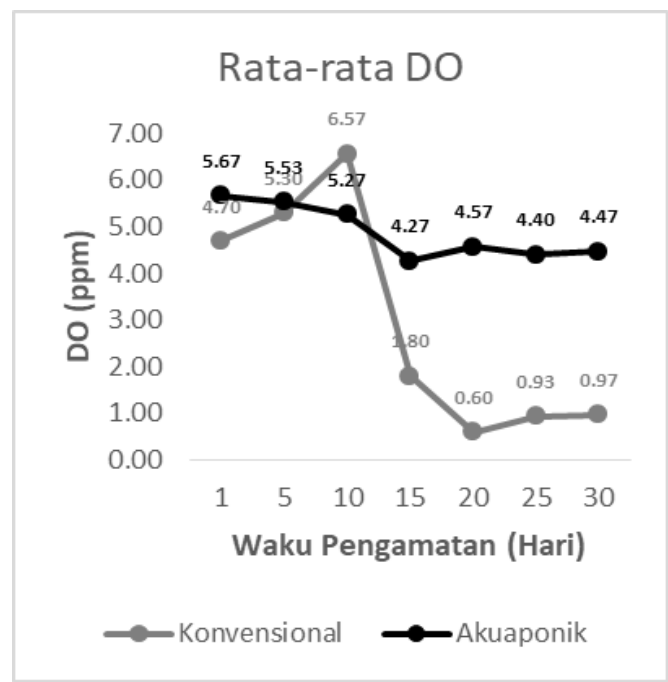

Gambar 2. Fluktuasi DO pada kedua sistem selama masa perlakuan 


\section{Derajat Keasaman (pH)}

Hasil pengamatan $\mathrm{pH}$ selama masa perlakuan dapat dilihat baik kolam akuaponik dan kolam konvensional menunjukan kisaran yang sama antara dua sistem ini yang berada pada kisaran 6-7 yang bisa dikatakan stabil dan menunjang kelangsungan hidup ikan air tawar (Mas'ud, 2014). Dikaitkan dengan oksigen terlarut, $\mathrm{pH}$ perairan dipengaruhi oleh oksigen terlarut dimana semakin kecil oksigen terlarut kencenderungan $\mathrm{pH}$ akan bersifat basa dan kondisi sebaliknya apabila oksigen terlarut ada dalam jumlah besar (Dauhan et al., 2014). Sejalan dengan hasil penelitian yang diperoleh konsentrasi oksigen terlarut yang relative stabil pada kolam akuaponik mengakibatkan $\mathrm{pH}$ yang relatif stabil pula.

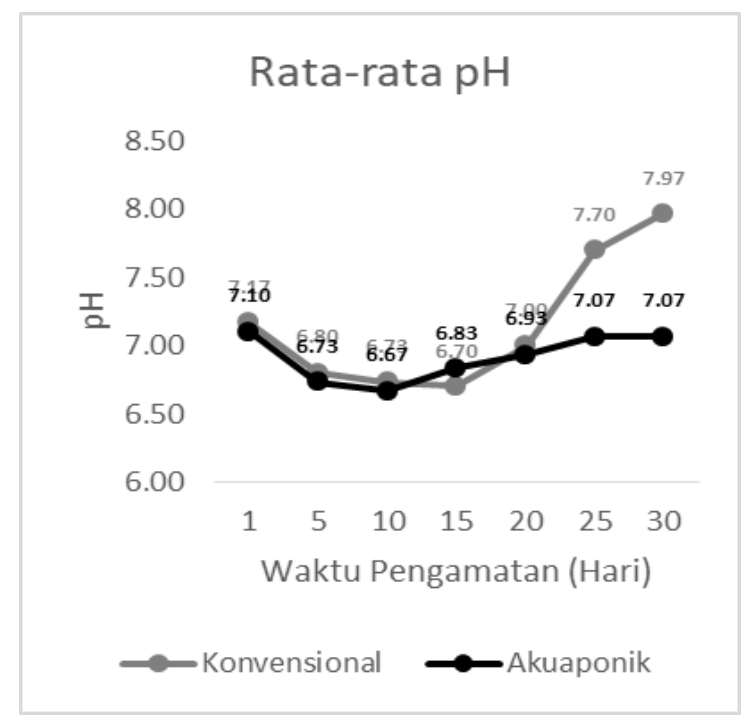

Gambar 3. Fluktuasi pH pada kedua sistem selama masa perlakuan

\section{Ammonia $\left(\mathbf{N H}_{3}\right)$}

Dari hasil diperoleh konsentrasi ammonia selama masa perlakuan, dapat dilihat bahwa pada kolam akuaponik konsentrasi amonia lebih rendah dibandingkan dengan konsentrasi pada kolam konvensional (Gambar 4). Hal ini berhubungan dengan laju konversi amonia menjadi nitrat yang dapat dilihat pada Gambar 5. Berdasarkan penelitaian yang dilakuakn oleh Putra dkk., (2011) Dauhan dkk.,
(2014); Effendi dkk., (2015), menyatakan bahwa sistem akuaponik dapat meningkatkan secara signifikan laju konversi ammonia menjadi nitrat. Selanjutnya konversi ammonia menjadi nitrat juga dipengaruhi oleh kelarutan oksigen yang dapat dilihat pada Gambar 2. dimana konversi amonia menjadi nitrat berlangsung optimum pada kondisi oksigen terlarut yang stabil (Mas'ud, 2014).

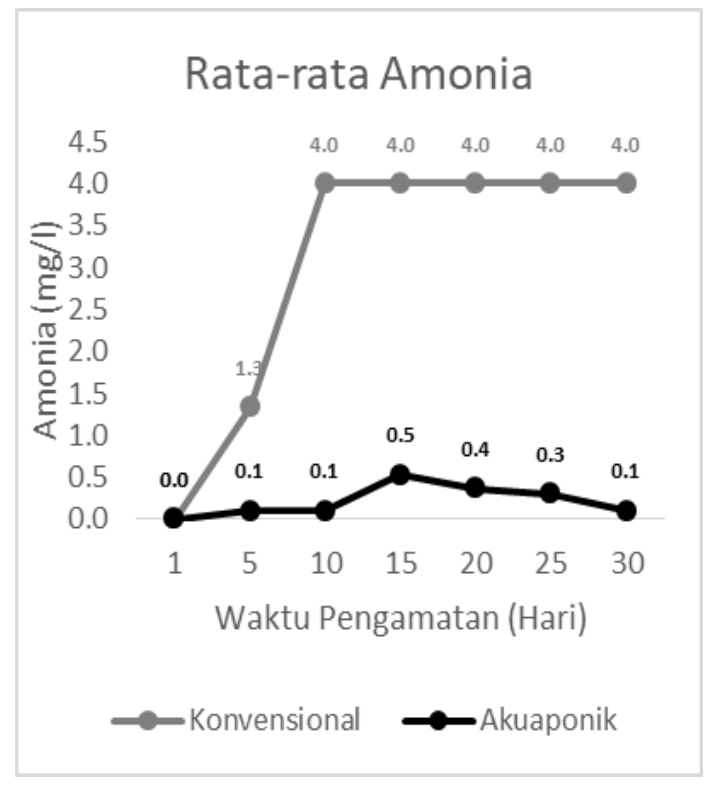

Gambar 4. Fluktuasi amonia pada kedua sistem selama masa perlakuan 


\section{Nitrat $\left(\mathrm{NO}_{3}\right)$}

Dari hasil yang diperoleh dapat dilihat bahwa pada kolam akuaponik terjadi peningkatan konsentrasi nitrat dibandingkan dengan kolam konvensional. Kenaikan konsentrasi nitrat pada hari ke 5 mengindikasikan terjadinya konversi ammonia menjadi nitrat melalui proses nitrifikasi (Gambar 5). Sejalan dengan hasil penelitian yang dilakukan oleh Dauhan dkk. (2014); Effendi dkk. (2015), yang menyatakan bahwa sistem akuaponik memiliki kemampuan untuk mengkonversi senawa ammonia menjadi nitrat. Dari hasil yang diperoleh dapat dilihat juga bawa konsentrasi nitrat mengalami penurunan pada hari ke 10 dan seterusnya seiring dengan lamanya masa perlakuan. Hal ini dapat dijelaskan dan berkaitan dengan pertumbuhan tanaman pada media akuaponik seperti dalam Dauhan et al. (2014) yang menyatakan bahwa semakin tinggi tingkat pertumbuhan tanaman maka asimilasi nitrat menjadi biomasa akan semakin besar pula yang berpengaruh pada konsentrasi nitrat dalam media.

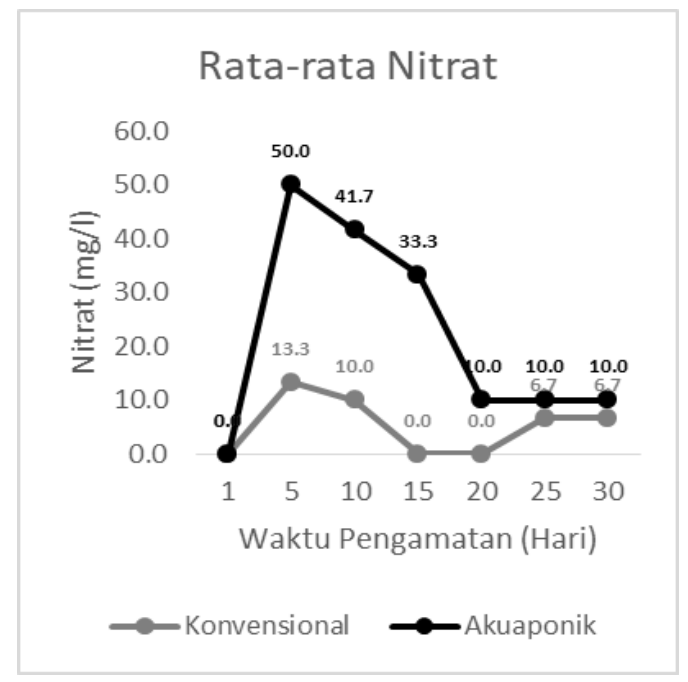

Gambar 5. Fluktuasi nitrat pada kedua sistem selama masa perlakuan

\section{Kajian pertumbuhan dan korelasinya dengan} kualitas air

Dari hasil percobaan yang dilakukan, pertumbuhan ikan nila (O. niloticus) yang dibudidayakan dengan menggunakan sistem akuaponik mengalami pertumbuhan lebih besar dibandingkan dengan sistem konvensional selama 30 hari masa perlakuan. Dari hasil diperoleh, ikan yang dipelihara dengan menggunakan sistem akuaponik mengalami laju petumbuhan sebesar $1,4 \%$ selama masa percobaan sedangkan ikan yang dipelihara dengan menggunakan sistem konvensional mengalami laju pertumbuhan sebesar $0,22 \%$ selama masa percobaan. Hasil ini diperoleh melalui analisa laju pertumbuhan spesifik/harian (SGR) yang menyatakan persentase pertumbuhan yang dicapai selama masa perlakuan Gambar 6.

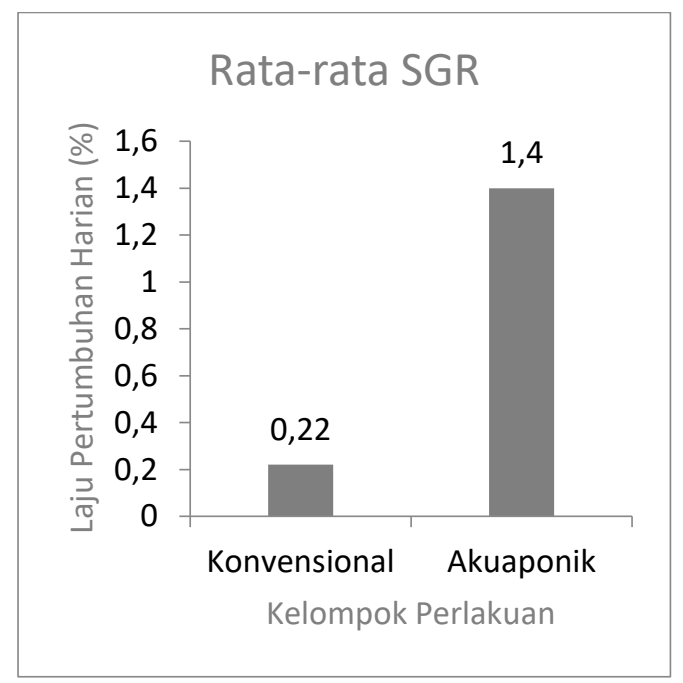

Gambar 6. Laju pertumbuhan harian ikan nila yang dipelihara pada kedua sistem selama masa perlakuan 
Kualitas air menjadi faktor utama yang mempengaruhi pertumbuhan ikan yang dibudidayakan (Alfia dkk., 2013). Dari hasil yang diperoleh dapat di lihat bahwa pada kolam akuaponik laju pertumbuhan lebih tinggi. Bila dikaitkan dengan kualitas air, kolam dengan sistem akuaponik memiliki kualitas air yang lebih baik dibanding dengan kolam konvensional dan hasil ini sejalan dengan hasil penelitian yang dilakukan oleh Dauhan dkk. (2014). Kolam akuaponik memiliki kemampuan untuk mereduksi senyawa-senyawa organik sisa metabolisme dan pakan ikan dalam kolam budidaya yang diketahui dapat menurunkan kualitas air dalam kolam budidaya dan dapat menurunkan pertumbuhan (Putra dkk., 2011; Dauhan dkk., 2014).

Selain berpengaruh positif terhadap pertumbuhan, sistem akuaponik juga berpengaruh positif terhadap kelangsungan hidup ikan nila yang dibudidayakan. Selama masa perlakuan sistem akuaponik mampu memberikan nilai kelangsungan hidup sebesar $100 \%$ dibandingkan dengan sistem konvensional sebesar $68 \%$. Hasil ini sejalan dengan hasil pertumbuhan yang diperoleh seperti halnya pertumbuhan, kelangsungan hidup ikan yang dibudidayakan sangat dipengaruhi oleh kualitas air (Dauhan dkk., 2014). Hasil pertumbuhan dan sintasan yang sejalan ini mengindikasikan hubungan antara kualitas air, petumbuhan dan sintasan ikan nila yang dibudidayakan dalam kolam akuaponik dan konvensional.

Pertambahan berat ikan selama penelitian tidak terlepas dari pakan yang diberikan. Hasil peritungan tingkat konversi pakan ikan nila ( $O$. niloticus) yang dipelihara dalam kolam konvensional dan kolam dengan sistem akuaponik disajikan dalam Gambar 7. Dapat dilihat bahwa perlakuan kolam konvensional menunjukan nilai tingkat konversi pakan lebih tinggi $(9,6 \mathrm{~kg})$ dari pada kolam dengan sistem akuaponik $(1,04 \mathrm{~kg})$. Diketahui bahwa pakan dalam hal ini kualitas dan kuantitasnya sangat berpengaruh terhadap pertumbuhan (Putra dkk., 2011). Dari hasil yang diperoleh dapat dilihat bahwa ikan yang dibudidayakan menggunakan sistem akuaponik mampu mengkonversi pakan menjadi biomasa tubuh lebih baik dibandingkan dengan kolam konvensional.

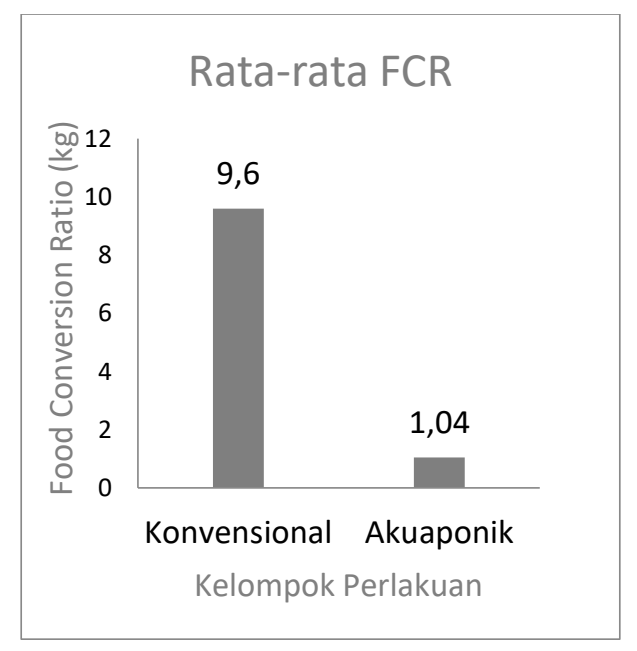

Gambar 7. Tingkat konversi pakan pada ikan nila yang dipelihara pada kedua sistem selama masa perlakuan

Sejalan dengan pertumbuhan dan sintasan, faktor lingkungan bisa menjadi penentu laju konversi pakan menjadi biomasa. Kualitas air yang baik akan meningkatkan nafsu makan dan feed intake (Setiawati dkk., 2008). Kualitas air yang baik juga akan mempengaruhi laju metaboisme dan asimilasi energi untuk pertumbuhan (Putra dkk., 2011). Sejalan dengan hasil penelitian yang diperoleh yaitu bahwa kualitas air yang baik dapat meningkatkan pertumbuhan melalui konversi pakan yang tinggi menjadi biomasa tubuh yang secara keseluruhan mempengaruhi kelangsungan hidup ikan yang dibudidayakan.

\section{SIMPULAN DAN SARAN}

Dari hasil penilitian yang dilakukan dapat ditarik beberapa kesimpulan diantaranya, sistem akuaponik lebih efektif dalam mengkonversi senyawa amonia menjadi senyawa nitrat dan menjaga kualitas air media budidaya ikan nila. Selanjutnya, kualitas air sangat berpengaruh terhadap pertumbuhan dan kelangsungan hidup ikan yang dibudidayakan dimana sistem akuaponik dengan kualitas air yang lebih terkontrol dapat meningkatkan pertumbuhan dan sintasan ikan yang dibudidayakan.

Untuk penelitan lebih lanjut perlu dilakukan beberapa pengukuran seperti waktu retensi air, parameter pertumbuhan tanaman, konversi bahan organik menjadi biomasa tanaman. Penggunaan jenis tanaman yang lebih bervariasi serta jenis ikan dan padat tebar juga perlu dilakukan untuk mengetahui sejauh mana efektivitas sistem akuaponik untuk peningkatan produksi dalam budidaya ikan air tawar. 


\section{DAFTAR PUSTAKA}

Alfia RA., Arini E., Elfitasari T. 2013. Pengaruh Kepadatan yang Berbeda terhadap Kelulushidupan dan Pertumbuhan Ikan Nila (Oreochromis niloticus) Pada Sistem Resirkulasi dengan Filter Bioball. Journal of Aquaculture Management and Technology, 2 (3): 86-93.

Dauhan RES., Efendi E., Suparmono. 2014. Efektifitas Sistem Akuaponik Dalam

Mereduksi Konsentrasi Amonia Pada Sistem Budidaya Ikan. e-Jurnal Rekayasa dan Teknologi Budidaya Perairan, 2(1): 297-302

Effendi H. 2003. Kualitas Air Bagi Pengelolaan Sumberdaya Dan Lingkungan Perairan. Kanisius. Yogyakarta. 257 hlm.

Effendi H., Utomo BA., Darmawangsa GM., Karo RE. 2015. Fitoremediasi Limbah Budidaya Ikan Lele (Clarias sp.) Dengan Kangkung (Ipomoea aquatica) Dan Pakcoy (Brassica rapa chinensis) Dalam Sistem Resirkulasi. Ecolab, 9 (2): 47-104.

Gupta VM., and Acosta BO. 2004. A Review of Global Tilapia Farming Practices. Aquaculture asia. World Fish Centre, 9 (1): 7 16

Hermawan D. 2015. Aplikasi Teknologi Aquaponik Pada Sistem Pemeliharaan Udang Vaname (Litopenaeus vannamei) Bersalinitas Rendah Dengan Tanaman Selada Pada Padat Tebar Berbeda. Jurnal Ilmu Pertanian dan Perikanan. 4(1): 79-85.

Marlina E., Rakhmawati. 2016. Kajian Kandungan Amonia Pada Budidaya Ikan Nila (Oreochromis niloticus) Menggunakan
Teknologi Akuaponik Tanaman Tomat (Solanum lycopersicum) Prosiding Seminar Nasional Tahunan Ke-V Hasil-Hasil Penelitian Perikanan dan Kelautan, 181-187.

Mas'ud F. 2014. Pengaruh Kualitas Air Terhadap Pertumbuhan Ikan Nila (Oreochromis sp.) Di Kolam Beton Dan Terpal. Grouper Faperik.

Nugroho RA., Pambudi LT., Chilmawati D., Haditomo AHC. 2012. Aplikasi Teknologi Aquaponic Pada Budidaya Ikan Air TawarUntuk Optimalisasi Kapasitas Produksi. Jurnal Saintek Perikanan, 8 (1): 46-51

Putra I., Mulyadi, Pamukas NA., Rusliadi. 2013. Peningkatan Kapasitas Produksi Akuakultur Pada Pemeliharaan Ikan Selais (Ompok sp) Sistem Aquaponik. Jurnal Perikananan Dan Kelautan, 18 (1): 1-10

Putra I., Setiyanto DD., Wahyjuningrum D. 2011. Pertumbuhan Dan Kelangsungan Hidup Ikan Nila (Oreochromis niloticus) Dalam Sistem Resirkulasi. Jurnal Perikanan dan Kelautan. 16 (1): 56-63.

Setiawati M., Sutajaya R., Suprayudi MA. 2008 Pengaruh Perbedaan Kadar Protein dan Rasio Energi. Aquacultura Indonesia. 9(1): 31-38.

Setijaningsih L., Gunadi B. 2016. Efektivitas Substrat Dan Tumbuhan Air Untuk Penyerapan Hara Nitrogen Dan Total Fosfat Pada Budidaya Ikan Berbasis Sistem Integrated Multi-Trophic Aquaculture (IMTA). Prosiding Forum Inovasi Teknologi Akuakultur. 169-176.

Wijaya O., Rahardja BS., Prayogo. 2014. Pengaruh Padat Tebar Ikan Lele Terhadap Laju Pertumbuhan Dan Survival Rate Pada Sistem Akuaponik. Jurnal Ilmiah Perikanan dan Kelautan. 6(1): 55-58 